\title{
Z „malej ojczyzny” do grodu Kraka
}

Zanim poznałem Prof. zw. dr. hab. Zygmunta Rutę, wówczas jeszcze docenta, wiele dobrego o Nim słyszałem. Mówiono mianowicie, że to nie tylko świetny badacz krajowych dziejów oświaty, który sobie i innym stawia wysokie progi wymagań naukowych i oczekuje należnego szacunku dla faktów, ale zarazem życzliwy i sympatyczny człowiek, Osoba szlachetna, uczynna i wrażliwa.

W marcu 1982 r. miałem okazje, przynajmniej częściowo, rozpoznać te wartości u Zygmunta Ruty, z którym wtedy spotkałem się pierwszy raz. W tamtym niespokojnym czasie stanu wojennego, kiedy obowiązywał zakaz zmiany miejsca pobytu obywatela bez zezwolenia odpowiednich władz, udałem się do Wyższej Szkoły Pedagogicznej im. Komisji Edukacji Narodowej w Krakowie w sprawie otwarcia przewodu habilitacyjnego. $\mathrm{Z}$ wcale niemałą tremą rozmawiałem wówczas, w jakże ważnej dla mnie sprawie, z prof. $\mathrm{dr}$ hab. Janem Kulpą (prorektorem), prof. dr. hab. Józefem Zbigniewem Białkiem (dziekanem Wydziału Humanistycznego), doc. dr. hab. Czesławem Majorkiem (dyrektorem Instytutu Pedagogiki) i doc. dr. hab. Zygmuntem Rutą (kierownikiem Katedry Historii Oświaty i Wychowania).

Paradoksalnie wydawać by się mogło, że w warunkach rygorystycznego prawa stanu wojennego, który mógł być uważany za główną przeszkodę w podjęciu przychylnej decyzji w interesującej mnie sprawie, efektem tychże rozmów stało się przyjęcie moich dokumentów przez Panią Stanisławę Gorczycę, kierowniczkę sekretariatu Wydziału Humanistycznego. To od Niej, ale dopiero kilka miesięcy później, dowiedziałem się, że znaczący wpływ na taki obrót moich starań, niosących nadzieję na rozpoczęcie postępowania habilitacyjnego, miał naprawdę Zygmunt Ruta. To właśnie On przekazał swoje stanowisko, przychylne moim zabiegom, dziekanowi Wydziału Humanistycznego. Mogłem się jedynie cieszyć z takiego obrotu sprawy. I w tym względzie, i w tym miejscu warto, a nawet należy odnieść się do konkretnej Osoby - Osoby, która na trwałe wpisała się swoim stylem postępowania pomocowego w moją świadomość i moje serce. Taką Osobą stał się Prof. zw. dr hab. Zygmunt Ruta, przeze mnie postrzegany jako ten, do którego można odnieść słowa Zbigniewa Herberta: Kim stalbym się, gdybym Cię nie spotkal.

Krótko mówiąc, tamto pierwsze, nieumówione spotkanie, które ustawicznie jawi mi się jako ważne wydarzenie w moim życiu, z upływem czasu i po dojrzalszej jego ocenie, przemienilo się $w$ trwałą postawę serdecznej wdzięczności. Ponowne spotkania, a było ich wcale niemało (nie zostały też do chwili obecnej przerwane), dostarczały mi coraz to nowych, ważnych psychologicznie spostrzeżeń, poszerzały obszary wzajemnego zaufania, sprzyjały odkrywaniu lustra duchowego Zygmunta Ruty. 
W rozległej przestrzeni tego osobowego lustra odbijają się jasnymi kolorami liczne wartości symbolizujące nauczyciela, pedagoga i naukowca.

W Profesorze Rucie bardzo łatwo odnaleźć nauczyciela. A jak zauważyłem nauczał chętnie, chętnie też był shuchany przez studentów. Ciepło, dobrze i miło wspominają Go dawni studenci z Krakowa i Kielc, gdzie wprowadzal edukowanych w świat wartości poznawczych (u podłoża których znajduje się prawda), ideowych (charakteryzujących się bezinteresownością) i moralnych (wyrażających się postępowaniem autotelicznym, czyli trwałym i powszechnym) oraz rozległy obszar koniecznych powinności zawodowych przyszłego nauczyciela polskiej szkoły. Ze studentami chętnie przebywał, na zajęciach ochoczo dzielił się z nimi najnowszymi osiągnięciami w naukach historyczno-pedagogicznych i aktualnymi potrzebami całej oświaty krajowej, nie unikając przy tym rzeczowej krytyki błędnych rozwiązań, które znacząco obniżały ogólny poziom kształcenia na wszystkich szczeblach i kierunkach nauczania.

Pan Profesor jest pedagogiem dużego formatu. $\mathrm{Na}$ co dzień cechowała Go perfekcja w wykonywaniu wszystkiego, co odnosiło się do obowiązków pedagoga kształcącego przyszłych nauczycieli. Szczególnie w odniesieniu do prac magisterskich i doktorskich, potrafił dostarczać wartości najbardziej istotnych: przyjazną atmosferę, osobisty wysiłek, najlepszą akademicką postawę wobec rozległej sfery zjawisk charakteryzujących obowiązki profesora-pedagoga wobec studentów. $Z$ tego też powodu pracownicy administracji oświatowej, nauczyciele praktycy i uczeni zajmujący się teoretycznymi zagadnieniami nauk o wychowaniu, z żywym zainteresowaniem reagują na wieść o każdej Jego nowej publikacji naukowej, bo dostrzegają w niej swojego mistrza, który wiele wymagał, ale też potrafił jeszcze więcej ofiarować. Jest to fakt niezmiernie istotny, niosący jakiś czytelny system dobrych znaków dla każdego nauczyciela, pozwalający mu odnaleźć w danym utworze osobowość Profesora, jawiącego się nie tylko jako homo faber-człowiek pracy, ale również jako homo ethicus - człowiek etyczny.

Ponieważ z funkcją nauczyciela i pedagoga w uczelni wyższej nierozłącznie wiąże się twórczość naukowa, więc i na tym polu odnajdujemy w Profesorze Rucie niestrudzonego pracownika naukowego. Zanim jednak zdobył upragniony tytuł profesora nauk humanistycznych, pokonał trudną drogę prowadzącą do osiągnięcia tak wysokiego awansu naukowego. Być może natchnienie i chęci odnajdywał w dawnym napisie znajdującym się nad Domem Jana Długosza w Krakowie, który brzmi: Nil est in homine bona mente melius. A więc zgodnie $\mathrm{z}$ tak brzmiącym przesłaniem umysł swoiście uprawiany, doskonalony, stawał się nakazem Jego twórczej pasji naukowej. Jej trwałym owocem były nie tylko pozycje książkowe, liczne artykuły i rozprawy (opracowania krytyczne, monograficzne), ale też promocje magisterskie, doktoranckie, habilitacyjne i profesorskie.

Kiedy obecnie studenci i pracownicy naukowi oraz wszyscy zainteresowani dziejami oświaty i wychowania, a także historią „małych ojczyzn" sięgają do bogatego ilościa, a jednocześnie zaskakującym różnorodnością problemów historyczno-pedagogicznych dorobku naukowego Profesora, $z$ niedowierzaniem uświadamiają sobie szerokie spektrum niełatwych zagadnień podejmowanych i rozwiązywanych ze świadomością odpowiedzialności i życiowych ambicji.

Jego publikacje nie tylko przypominają i zarazem utrwalają edukacyjną przeszłość, obrazują skomplikowaną współczesność oświatową wraz z zagubionym 
w niej człowieku, ale są też głosem kreującym przyszłość szkoły w kraju nad Wisłą i Odrą.

Wszystkie jednak te trzy odniesienia implikuje ostatecznie ten sam świat wartości gorące pragnienie lepszej przyszłości dla nauki polskiej i całego szkolnictwa krajowego ukierunkowanego na kształcenie człowieka myślącego. Myślącego w wymiarze globalnym i w równym stopniu w przestrzeni regionalnej.

Wielu piszących prace o tematyce regionalnej i interesujących się przeszłością własnej „małej ojczyzny” szukać będzie tych opracowań, które mieszczą się w bogatym dorobku naukowym Profesora Z. Ruty, a stanowiącym zbiorowe monografie wybranych miast Małopolski, w tym stron rodzinnych. Od nich właśnie, a dokładnie od Dąbrowy Tarnowskiej, niedaleko której leży wieś Borusowa, najmniejsza z czasów dzieciństwa i okresu dorastania ojczyzna Z. Ruty, w przeszłości należąca do spadkobierców po hr. Adamie Potockim, zaczęła się przygoda naukowa Profesora $\mathrm{z}$ historią regionalną. Podobnie jak w pierwszej połowie dwudziestego stulecia prof. Franciszek Bujak zapoczątkował badania nad dziejami regionów, tak w drugiej jego części Profesor Ruta nie tylko je kontynuował, ale także uzasadniał ich szczególną rolę poznawczą, wychowawczą i edukacyjną opartą na kulturze lokalnej społeczności, na jej tradycji rozumianej jako wartości odziedziczone po przodkach, specyficzny byt podarowany przez historię. Te „zaszłe” elementy przeszłości, oparte na historycznym ,portrecie źródłowym” lokalnej ojczyzny wzbogacał, modyfikował i uzupełniał o składniki niesione przez upływający czas, albo jeszcze jako odniesienie społeczne do minionego czasu.

$\mathrm{W}$ podejmowanej szeroko kwestii historii regionalnej, dostrzegał jej znaczenie dla wychowania patriotycznego i myśli pedagogicznej, która nakazuje, by odwoływać się do poglądów, obyczajów, zasad i świadomości, w wielkiej przestrzeni czasu pielgrzymujących między pokoleniami, traktowanych jako wartości ideowe, charakterystyczne dla mieszkańców danego obszaru terytorialnego. A obszar terytorialny to ludzie i ziemia, o której W. Szymborska pisze:

\footnotetext{
Ziemio ojczysta, ziemio jasna

Nie będę powalonym drzewem.

Codziennie mocniej w Ciebie wrastam

Radościq, smutkiem, duma, gniewem.

Nie będę jak zerwana nić.

Odrzucam pusto brzmiqce slowa.

Można kochać Cię - i żyć,

Ale nie można owocować
}

Dla Profesora Ruty małą ziemią ojczystą jest Borusowa, a w niej dom rodzinny. Wyniósł $\mathrm{z}$ niego nie tylko wartości wychowawcze ograniczające się wyłącznie do kultury, obrzędów, obyczajów czy pieśni ludowej, ale przede wszystkim wartości sięgające głębiej, do religii i patriotyzmu, do wartości poznawczych (odkrywczość, prawdziwość, twórczość, odpowiedzialność, autentyzm, dialog, zaangażowanie, szacunek itp.). Zadecydowały one o Jego orientacji życiowej i wyznaczyły ducha oraz kierunek rozwiązywania własnego rozwoju.

Jan Paweł II w encyklice Fides et ratio podkreśla, że: tylko dzięki prawdziwym wartościom czlowiek może stawać się lepszy, rozwijać w petni swojq naturę. Czlowiek nie znaj- 
duje prawdziwych wartości zamykajac się $w$ sobie, ale otwierajac się $i$ poszukujac ich takie $w$ wymiarach transcendentalnych wobec niego samego.

Jeżeli nie można być w pełni czlowiekiem bez tego wszystkiego, co zostało zamknięte w Papieskich słowach, to cała „Odyseja” Zygmunta Ruty z Płaskowyżu Tarnowskiego do grodu Kraka, któremu serce ofiarował - ponad wszelką wątpliwość wskazuje, że osiagnął On pełnię Człowieczeństwa. Nie ma przy tym wątpliwości, że u podstaw tego życiowego sukcesu tkwi założenie, że źródłem jego osiagnięcia stało się świadome poszukiwanie przez Niego i ustalanie hierarchii wartości oraz pozytywna odpowiedź emocjonalna na ich urzeczywistnianie w codziennym działaniu.

Dlatego też chciałbym Szanowny Profesorze, Drogi Przyjacielu, ażebyś zechciał przyjąc pełne szczerego uznania gratulacje za tak konsekwentne działanie, potwierdzone gorliwie wykonywaną praca na rzecz służby nauce, ojczystej ziemi i po prostu drugiemu człowiekowi: modelowaniu jego formacji i obronie jego dóbr humanistycznych. Pochłonięty edukacyjnym i naukowym wysiłkiem, wbrew wszelkim doznawanym przeciwieństwom, trafnie odczytałeś kategorię czasu, inwestując go w dążenie do osiagnięcia tajemnicy godnego i twórczego życia, którego stałeś się czytelnym symbolem. 